\title{
CYTOTOXICITY OF REGULAR AND FAST SET BIOCRAMIC MATERIALS
}

\author{
Loai Alsofi*
}

\begin{abstract}
Aim: To compare the cytotoxic effect of regular and fast set Root Repair Materials using oral epithelial cells (OEC).

Materials and methods: The cytotoxicity of the two forms was tested against OEC cells using Sulfo-rhodamine B (SRB) assay. The cells were exposed to the test compound for $72 \mathrm{hrs}$.

Results: Both fast and regular set root repair materials showed a considerable cytotoxicity against OEC cells with $\mathrm{IC}_{50}$ of 3.0 and $3.4 \mu \mathrm{g} / \mathrm{ml}$, respectively. Despite their moderate cytotoxic effect, the resistant fraction was relatively high for Fast and regular root repair composites (R-values equal $35.6 \%$ and $32.2 \%$, respectively).

Conclusions: Both fast and regular set of EndoSequence Root Repair Materials have a considerable cytotoxicity against OEC cells. Despite their moderate cytotoxic effect against the cells the resistant fraction was relatively high for both.
\end{abstract}

\section{INTRODUCTION}

Materials used for root repair or root-end filling should be biocompatible and non-toxic to perform their bioactive effect with less irritation to the adjacent tissues. The biocompatibility of material is defined as the material is to act within appropriate host response in a specific situation ${ }^{(1)}$. The host response to the introduced material depends on its chemical reactivity. The chemical composition of the biomaterial will affect cell migration, adhesion, differentiation, proliferation and cytotoxicity.
EndoSequence Root Repair material (regular set, Brassler USA, Savannah, GA, USA) was developed as an alternative to MTA (2) and was released in a ready to use premixed putty form. Unlike MTA, the material is malleable and it is hydrophilic and aluminum and bithmus oxide free $^{(3,4)}$. The regular set material was used as a retrofilling material during apical surgery, pulp capping and perforation repair. Recent studies showed that the regular set material induces similar percentage of dental pulp cells (DPCs) viability and

\footnotetext{
* Assistant Professor, Department of Endodontics, Faculty of Dentistry, King Abdulaziz University
} 
proliferation rate compared to MTA. Moreover, regular set material showed similar biocompatibility and promotion of human bone marrow cell proliferation and survival. It also causes higher cell proliferation than other silicate materials ${ }^{(5)}$. The regular set material exhibited more bioactivity compared to MTA ${ }^{(3)}$ with similar cytotoxicity as ProRoot MTA (4). Other studies showed that the regular set material is biocompatible and promote cell proliferation and improve their survival rate similar to MTA ${ }^{(2,5)}$. The study of Coaguila et al in 2016 showed that the regular set material is less cytotoxic than MTA angelus and Super EBA ${ }^{(6)}$.

Recently, Brassler introduced a new putty form of the EndoSequence root repair material with fast setting time. The new material sets within 15 minutes compared to regular set material which requires more than 48 hours to set ${ }^{(7)}$. The material has similar composition as the regular set one. Upon testing the fast set material, it promoted greater survival and differentiation of stem cells of the apical papilla and increased odontoblastic marker DSSP similar to the regular set one ${ }^{(8)}$.

The difference in chemical composition between the two forms of EndoSequence, due to adding elements to shorten the setting time, may result in different cell response ${ }^{(9)}$. When comparing regular set to the fast set, both materials showed similar effect on the proliferation and viability of the apical papilla stem cells, but fast set had a less mineralizing effect than the regular set results ${ }^{\left({ }^{(8)}\right.}$.

No previous study in the literature was published comparing the cytotoxicity of the regular and fast set forms of EndoSequence Root Repair Material. So, the aim of the current study was to compare the cytotoxicity of the regular and fast set of the EndoSequence Root Repair Material using the human oral epithelial cells (OEC)

\section{MATERIALS AND METHODS}

\section{Material selection}

The selected materials were the EndoSequence Root Repair material (Brassler USA, Savannah, GA, USA) in two forms. The first form is the putty form with regular set and the second one was the fast set form.

\section{Cytotoxicity testing}

\section{Chemicals and drugs}

Sulfarhodamine was purchased from SigmaAldrich (St. Louis, MO, USA). Tricloroacetic acid and other materials were of the highest available commercial grade supplied from the research lab.

\section{Cell culture}

Human oral epithelial cells (OEC) were selected from the research lab. Cells were maintained in DMEM. Media were supplemented with streptomycin $(100 \mu \mathrm{g} / \mathrm{mL})$, penicillin $(100 \mathrm{IU} / \mathrm{mL})$ and heat-inactivated fetal bovine serum $(10 \%, \mathrm{v} / \mathrm{v})$ in a humidified, $5 \%(\mathrm{v} / \mathrm{v}) \mathrm{CO}_{2}$ atmosphere at $37^{\circ} \mathrm{C}$.

\section{Cytotoxicity assays}

The cytotoxicity of the two forms was tested against OEC cells by Sulfo-rhodamine B (SRB) assay as previously described (10). Exponentially growing cells were collected using $0.25 \%$ TrypsinEDTA and plated in 96-well plates at 2000-5000 cells/well. Cells were exposed to the compounds for $72 \mathrm{~h}$ and subsequently fixed with TCA (10\%) for $1 \mathrm{~h}$ at $4{ }^{\circ} \mathrm{C}$. After being washed several times, cells were exposed to $0.4 \%$ SRB solution for $10 \mathrm{~min}$ in dark place and subsequently washed with $1 \%$ glacial acetic acid. After drying overnight, Tris- $\mathrm{HCl}$ was used to dissolve the SRB-stained cells and color intensity was measured at $540 \mathrm{~nm}$.

$\%$ Cell viability $=(100-\mathrm{R}) \times\left(1-\frac{[\mathrm{D}]^{\mathrm{m}}}{\mathrm{K}_{\mathrm{d}}{ }^{\mathrm{m}}+[\mathrm{D}]^{\mathrm{m}}}\right)+\mathrm{R} \ldots$ (Eq. 1) 
Where $[R]$ is the residual unaffected fraction (the resistance fraction), [D] is the drug concentration used, $\left[\mathrm{K}_{\mathrm{d}}\right]$ is the drug concentration that produces a $50 \%$ reduction of the maximum inhibition rate and $[\mathrm{m}]$ is a Hill-type coefficient. $\mathrm{IC}_{50}$ was defined as the drug concentration required to reduce color intensity by $50 \%$ of that of the control (i.e., $\mathrm{K}_{\mathrm{d}}=\mathrm{IC}_{50}$ when $\mathrm{R}=0$ and $\left.\mathrm{E}_{\max }=100-\mathrm{R}\right)^{(11)}$.

\section{RESULTS}

SRB-U assay was used to assess the potential cytotoxicity of the regular and fast set root repair materials against normal oral epithelium cell line over concentration range $0.1-1000 \mu \mathrm{g} / \mathrm{ml}$. The cytotoxicity parameters, $\mathrm{IC}_{50}$ and R-value were calculated using $\mathrm{E}_{\max }$ model as described in the methods section. Both fast and regular root repair materials showed a considerable cytotoxicity against $\mathrm{OEC}$ cells with $\mathrm{IC}_{50}$ of 3.0 and $3.4 \mu \mathrm{g} /$ $\mathrm{ml}$, respectively, Figure $1 \mathrm{~A}$ and B. Despite their moderate cytotoxic effect against the cells, it is worth to mention that the resistant fraction was relatively high for Fast and regular root repair composites (R-values equal $35.6 \%$ and $32.2 \%$, respectively) Figure $1 \mathrm{~A}$ and $\mathrm{B}$.

\section{DISCUSSION}

Assessing the material cytotoxicity using cell culture is the first stage of biocompatibility evaluation. The biocompatibility is affected by material chemical composition as well as ion release rate and its geometrical design.

Different cell lines were utilized to study the cytotoxicity of endodontic root repair materials. Dental pulp cells ${ }^{(2)}$, human dermal fibroblasts ${ }^{(4)}$, human osteoblasts $^{(14)}$, periodontal ligament fibroblasts ${ }^{(6)}$, and murine fibroblasts ${ }^{(15)}$. In the current study we selected the human epithelial cells.
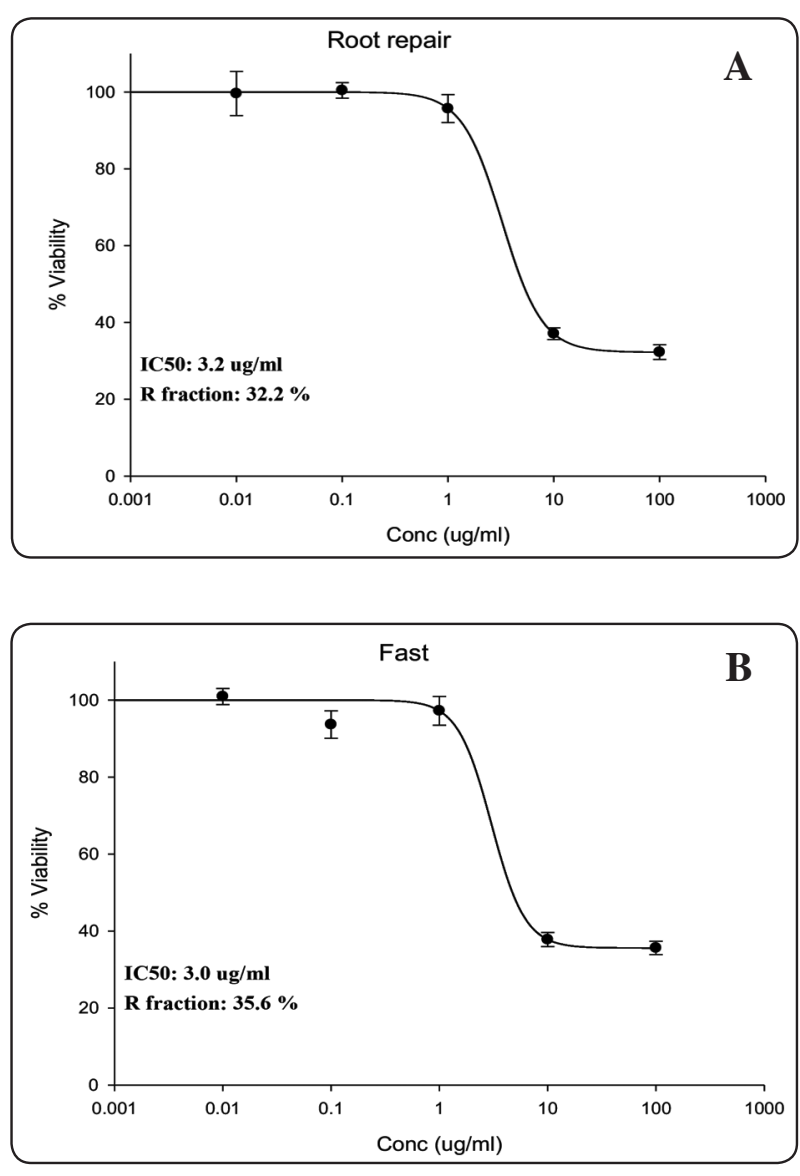

Fig. (1) A, cytotoxicity of regular set form of the root repair material against oral epithelial cells, IC50 and R-value were $3.0 \mu \mathrm{g} / \mathrm{ml}$ and $35.6 \%$, respectively. B, cytotoxicity of fast set form of the root repair material against oral epithelial cells, IC50 and R-value were $3.4 \mu \mathrm{g} / \mathrm{ml}$ and $32.2 \%$, respectively.

Different methods for cytotoxicity assessement studies have been used, for example the methylthiazoldiphenyl-tetrazolium method (MTT) ${ }^{(16)}$, multiparametric assay ${ }^{(17)}, 2,5$-diphenyltetrazolium bromide assay ${ }^{(18)}$ and other techniques ${ }^{(19)}$. In the current study we used the sulforhodamine B (SRB) assay for measuring the cell density. The method is based on the measurement of cellular protein content and the method's sensitivity is comparable to those of other methods ${ }^{(20)}$.

Early studies to evaluate the cytotoxicity of the Brasseler EndoSequence Root Repair Materials have shown similar cytotoxicity levels to those of ProRoot MTA and MTA-Angelus ${ }^{(14)}$. 
In the current study both forms showed a considerable cytotoxicity against OEC, which came in contrary with the study of Damas et al in 2011. This could be related to the time duration of the current test that lasts for 72 hrs where in Damas study the test lasts for $24 \mathrm{hrs}$ only. The type of cell line and the method utilized for vitality testing could modify the results obtained.(4). Moreover, another study showed that the regular set material reduced the bioactivity and alkaline phosphatase activity of osteoblast like cells over time which came in agreement with the results of the current study ${ }^{(19)}$. However, Ciasca et al in 2012 found that regular set material was more cytotoxic to human osteoblasts compared to MTA without significant difference ${ }^{(14)}$.

In the current study, the resistant fraction was relatively high for the fast set material, it was also higher than that of the regular set material. This could be related to the faster setting time of the fast set form compared to the regular set which does not set even after 48 hours ${ }^{(7)}$. Also, the change of elemental proportions in the fast set to shorten the setting time may influence its cytotoxic effect.

\section{CONCLUSIONS}

Both the fast and regular set of EndoSequence Root Repair Materials have a considerable cytotoxicity against OEC cells. Despite their moderate cytotoxic effect against the cells, resistant fraction was relatively high for both.

\section{REFERENCES}

1. Williams DF. On the mechanisms of biocompatibility. Biomaterials. 2008; 29 ( 20):2941-53.

2. Machado J, Johnson JD, Paranjpe A. The effects of Endosequence root repair material on differentiation of dental pulp cells. J Endod 2016;42(1):101-5.

3. Ma J, Shen Y, Stojicic S, Haapasalo M. Biocompatibility of two novel root repair materials. J Endod 2011;37(6):793-8.

4. Damas BA, Wheater MA, Bringas JS, Hoen MM. Cytotoxicity comparison of mineral trioxide aggregates and EndoSequence bioceramic root repair materials. J Endod 2011;37(3):372-5.

5. Chen I, Salhab I, Setzer FC, Kim S, Nah HD. A new calcium silicate-based bioceramic material promotes human osteo- and odontogenic stem cell proliferation and survival via the extracellular signal-regulated kinase signaling pathway. J Endod 2016;42(3):480-6.

6. Coaguila-Llerena H, Vaisberg A, Velasquez-Huaman Z. In Vitro Cytotoxicity Evaluation of Three Root-End Filling Materials in Human Periodontal Ligament Fibroblasts. Braz Dent J 2016;27( 2):187-191.

7. Charland T, Hartwell GR, Hirschberg C, Patel R. An Evaluation of Setting Time of Mineral Trioxide Aggregate and EndoSequence Root Repair Material in the Presence of Human Blood and Minimal Essential Media. J Endod 2013;39(8):1071-2.

8. Miller AA, Takimoto K, Wealleans J, Diogenes A. Effect of 3 Bioceramic Materials on Stem Cells of the Apical Papilla Proliferation and Differentiation Using a Dentin Disk Model. J Endod 2018;44(4):599-603.

9. Perez AL, Spears R, Gutmann JL, Opperman LA Osteoblasts and MG-63 Osteosarcoma Bells behave Differently When in Contact With ProRoot MTA and White MTA. Int Endod J 2003;36( 8):564-70.

10. Skehan P, Storeng R, Scudiero D, Monks A, McMahon J, Vistica D, Warren JT, Bokesch H, Kenney S, Boyd MR New Colorimetric Cytotoxicity Assay for Anticancer-Drug Screening. J Natl Cancer Inst 1990;82(13):1107-12.

11. Mahmoud AM,Al-Abd AM, Lightfoot DA, El-Shemy HA. Anti-Cancer Characteristics of Mevinolin Against Three Different Solid Tumor Cell Lines was not Solely p53dependent. J Enzyme Inhib Med Chem 2012;27(5):673-9.

12. Misuriya A, Bhardwaj A, Bhardwaj A, Aggrawal S, Kumar PP, Gajjarepu S. A Comparative Antimicrobial Analysis of Various Root Canal Irrigating Solutions on Endodontic Pathogens: An in Vitro Study. J Contemp Dent Pract 2014;15(2):153-60.

13. Kruger-Krasagakes S, Moller A, Kolde G, Lippert U, Weber M, Henz BM. Production of Interleukin-6 by Human Mast Cells and Basophilic Cells. J Invest Dermatol 1996;106( 1):75-9.

14. Ciasca M, Aminoshariae A, Jin G, Montagnese T, Mickel A. A Comparison of the Cytotoxicity and Proinflammatory Cytokine Production of EndoSequence Root Repair 
Material and ProRoot Mineral Trioxide Aggregate in Human Osteoblast Cell Culture Using Reversetranscriptase Polymerase Chain Reaction. J Endod 2012; 38 (4):486-9.

15. Nair AV, Nayak M, Prasada LK, Shetty V, Kumar CNV, Nair RR. Comparative Evaluation of Cytotoxicity and Genotoxicity of Two Bioceramic Sealers on Fibroblast Cell Line: An in vitro Study. J Contemp Dent Pract 2018; 19 (6) :656-661.

16. da Silva E, Zaia AA, Peters OA. Cytocompatibility of Calcium Silicate-Based Sealers in a Three-Dimensional Cell Culture Model. Clin Oral Invest 2017; 21 (5): 1531-6.

17. Souza LC, Yadlapati M, Dorn SO, Silva R, Letra A.
Analysis of Radiopacity, $\mathrm{pH}$ and Cytotoxicity of a new Bioceramic Material. J Appl Oral Sci 2015; 23(4):383-9

18. Chakar S, Changotade S, Osta N, Khalil I. Cytotoxic Evaluation of a new Ceramic-Based Root Canal Sealer on Human Fibroblasts.Eur J Dent 2017; 11 (2):141-8.

19. Modareszadeh MR, Di Fiore PM, Tipton DA, Salamat N. Cytotoxicity and Alkaline Phosphatase Activity Evaluation of Endosequence Root Repair Material. J Endod 2012; 38 (8): 1101-5.

20. Martin A, Clynes M. Comparison of 5 Microplate Colorimetric Assays for in Vitro Cytotoxicity Testing and Cell Proliferation Assays. Cytotechnology 1993;11(1):49-58. 